\title{
MENUMBUHKEMBANGKAN SIKAP KRITIS DAN TOLERANSI SISWA MELALUI PENINGKATAN PENGETAHUAN SISWA TENTANG ILMU NEGARA
}

\author{
Amanda Raissa ${ }^{1}$, Astria Yuli Satyarini Sukendar ${ }^{2}$, Tomy Michael ${ }^{3}$ \\ 1,2,3 Fakultas Hukum, Universitas 17 Agustus 1945 Surabaya, Indonesia \\ 1amandaraissa090698@gmail.com, ${ }^{2}$ riniskndar@gmail.com, ${ }^{3}$ tomy@untag-sby.ac.id
}

\begin{abstract}
ABSTRAK
Abstrak: Ilmu Negara menjadi suatu cabang ilmu yang cukup menarik untuk diketahui dan juga dipelajari oleh banyak orang, karena dalam mempelajari ilmu Negara maka pengetahuan dan juga pemahaman kita terhadap berbagai macam hal yang dalam kenegaraan dan juga bentuk-bentuk negara akan terus berkembang. Dengan mempelajari ilmu negara juga diharapkan akan menimbulkan pemikiran yang kritis terhadap segala permasalahan yang berkaitan dengan negara-negara yang ada di penjuru dunia, serta menimbulkan rasa toleransi antara masyarakat negara satu dengan negara yang lain. oleh karena itu dalam penyuluhan pada kali ini para siswa di SMA 17 Agustus 1945 Surabaya akan mendapatkan pemahaman mengenai ilmu negara mulai dari bentuk-bentuk negara di seluruh penjuru dunia serta ciri-ciri suatu negara. Adapun penyuluhan yang diberikan akan menjadikan siswa dan juga siswi sudah mulai mengenal tentnang bentuk-bentuk negara dari negaranya sendiri maupun negara lain sehingga akan timbul rasa saling menghargai antar negara yang satu dengan negara yang lain sejak dini.

Kata Kunci: Sikap Siswa, Kritis, Toleransi, Ilmu Negara

Abstract: State Science becomes a branch of science that is quite interesting to know and also studied by many people, because in studying State science, our knowledge and also understanding of various kinds of things in the state and also the forms of the state will continue to develop. By studying state science it is also hoped that it will lead to critical thinking on all issues relating to countries around the world, as well as to create a sense of tolerance between the people of one country and another. Therefore, in this counseling, students at SMA 17 Agustus 1945 Surabaya will get an understanding of state science starting from the forms of the state in all corners of the world and the characteristics of a country. The counseling will make students and students have started to recognize about the forms of the state from their own country or other countries so that there will be a sense of mutual respect between one country with another country early on.
\end{abstract}

Keywords: Student attitudes, critical, tolerance, State science

\section{A. LATAR BELAKANG}

Pengetahuan merupakan suatu hal yang sangat berharga karena dengan adanya pengetahuan seseorang akan menjadi lebih percaya diri dan juga kristis tentang segala macam permasalahan dan juga pembaruan yang terjadi di berbagai Negara (Ritaudin, 2014), (Nugroho, 2015). Pengetahuan haruslah terus diberikan kepada semua orang terutama kepada anak-anak, karena nantinya anak-anak merupakan tonggak utama yang menentukan 
kemajuan suatu bangsa dan juga sebagai suatu pendobrak yang nantinya akan terus menghasilkan hal-hal dan juga inovasi-inovasi baru terkait dengan pendidikan, kesehatan, ekonomi, social dan budaya serta hal-hal lain yang dapat memajukan bangsa agar menjadi suatu negara yang makmur (Kamal, 2016). Oleh karena itu dalam hal ini mahasiswa dari Universitas 17 agustus melakukan penyuluhan terkait Ilmu Negara kepada Siswa dan Siswi Sekolah Menengah Atas 17 Agustus 1945 Surabaya sebagai bentuk realisasi dari hak pendidikan anak yang dimana anak- anak berhak mendapatkan pendidikan non formal guna meningkatkan kemampuan dari peserta didik dalam mengetahui bentuk-bentuk negara, ciri-ciri negara dan juga ideologi-ideologi yang ada diselurruh negara di penjuru dunia (Supriyoko, 2010).

\section{B. METODE PELAKSANAAN}

Menggunakan pola tatap muka kepada para siswa dan siswi SMA 17 Agustus 1945 Surabaya sebanyak 40 orang, yang dimana penyuluhan ini diawali dengan adanya pemberian materi yang dibawakan oleh para pemateri terkait dengan ilmu negara seperti bentuk-bentuk negara, ciri-ciri negara dan juga hal-hal lain yang terkait dengan keunggulan serta kelemahan bentuk negara di seluruh penjuru dunia. Kemudian dilanjutkan dengan proses pembentukan kelompok belajar yang nantinya para siswa dan siswi di haruskan mempertimbangkan bentuk dan juga ideologi negara dengan harus mempelajari sejarah dari bentuk dan juga ideologi-idelogi yang di anut oleh beberapa negara melalui literature baik dari internet, jurnal dan juga buku. Proses pembentukan kelompok belajar ini juga dilanjutkan dengan proses tanya jawab kepada para siswa dan siswi SMA 17 Agustus 1945 Surabaya. Guna mengetahui bentuk dan juga ideologi yang di anggap oleh para peserta tersebut dapat mensejahterakan masyarakat dari negara tersebut. Adapun dalam pelaksanaannya penyuluhan ini memiliki tujuan agar:

1. Siswa dan Sisiwi SMA 17 Agustus 1945 Surabaya dapat memahami bentuk-bentuk negara yang ada di seluruh penjuru dunia

2. Siswa dan Siswi SMA 17 Agustus 1945 Surabaya dapat lebih kritis dalam mengahadapi segala hal terkait permasalahan yang ada pada setiap negara

3. Menimbulkan rasa saling menghargai antara negara satu dengan negara lain yang memiliki banyak perbedaan

4. Siswa dan Siswi Lebih peka terhadap isu-isu social yang terjadi baik dalam negara sendiri maupun negara lain.

5. Membentuk kelompok belajar bagi siswa dan siswi guna membahas berbagai hal terkait ilmu negara 


\section{HASIL DAN PEMBAHASAN}

\section{Pengenalan Bentuk Negara, Ciri-Ciri Negara, Ideologi Negara}

Anak-anak merupakan generasi pendobrak yang pada nantinya akan menghasilkan hal-hal baru dan juga inovasi-inovasi yang terbarukan guna membangun negaranya menjadi negara yang maju dan kaya. Untuk mencetak anak-anak yang berguna bagi nusa dan bangsa perlulah adanya pendidikan,Desakan dan tuntutan untuk menghasilkan pendidikan yang berkualitas terus didengungkan (Asmaun, Prasetyo, \& Angga, 2012) oleh karena itu perlulah adanya pendidikan baik pendidikan formil di sekolah, maupun pendidikan nonformal meliputi pendidikan kecakapan hidup, pendidikan anak usia dini, pendidikan kepemudaan, pendidikan pemberdayaan perempuan, pendidikan keaksaraan, pendidikan keterampilan dan pelatihan kerja, pendidikan kesetaraan, serta pendidikan lain yang ditujukan untuk mengembangkan kemampuan peserta didik, terdiri atas lembaga kursus, lembaga pelatihan, kelompok belajar, pusat kegiatan belajar masyarakat, dan majelis taklim, serta satuan pendidikan yang sejenis. Begitu pentingnya pendidikan, sehingga suatu bangsa dapat diukur apakah bangsa itu maju atau mundur dalam hal ini maka Keberhasilan pendidikan bukan hanya dapat diketahui dari kualitas individu, melainkan juga keterkaitan erat dengan kualitas kehidupan masyarakat, berbangsa dan bernegara (Idi, 2011).

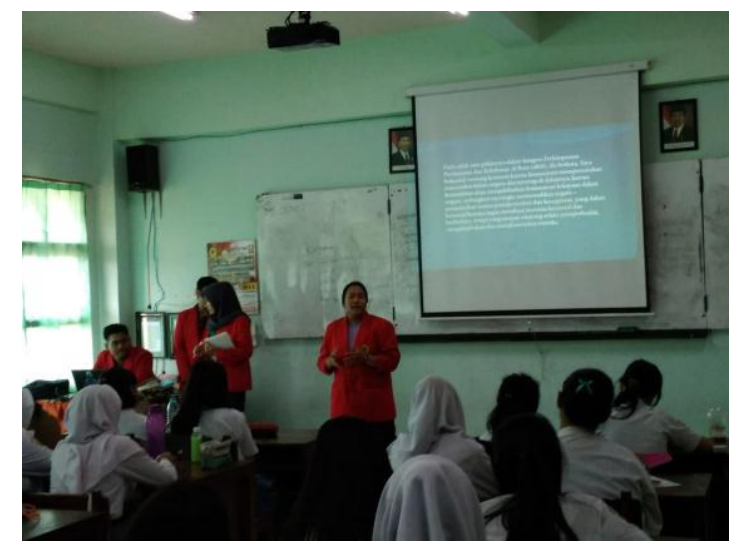

Gambar 1. Penyampaian Materi tentang Bentuk-bentuk Negara

Dalam hal ini penyuluhan-penyuluhan terkait dengan pengetahuan sosial sangatlah diperlukan oleh generasi muda agar nantinya dapat mengasah kepekaan serta mengasah pola pikir yang kritis mereka dalam menanggapi isu-isu sosial terkait negara-negara yang ada dipenjuru dunia. Maka dalam penyuluhan yang diberikan kepada siswa dan siswi ini pemateri memberikan materi-materi kepada siswa dan siswi kelas $\mathrm{X}$ IPS SMA 17 Agustus 1945 tentang bentuk-bentuk negara yang ada diseluruh penjuru dunia yang dalam pemaparan tersebut memiliki tujuan agar siswa dan siswi tersebut dapat membedakan bentuk-bentuk negara yang ada serta mengetahui ciri-ciri dari suatu negara yang 
memiliki bentuk tertentu yang mungkin memiliki perbedaan yang jauh dengan negaranya Indonesia. Dalam pemaparan yang dipaparkan oleh pemateri, pemateri juga turut memaparkan adanya ideologi-ideologi yang di anut oleh berbagai negara yang dimana ideologi tersebut memiliki peran yang penting dalam kehidupan suatu negara. peserta juga di ajak untuk mengetahui apa ideologi yang di anut oleh negaranya Indonesia yaitu ideologi Pancasila. Pancasila sebagai ideologi bangsa Indonesia merupakan sesuatu yang dikonstruksi oleh para pemikir atau elit politik yang memandang perlu adanya sebuah sistem konvensi yang dapat menjadi kekuatan pengikat mental masyarakat (Rizal Mustansyi, n.d.). Dengan adanya pemberian materi tersebut siswa dan siswi akan mengetahui tentang Negara-negara lain yang ada di penjuru dunia serta mengetahui sejarah dari adanya ideologi yang dianut oleh banyak Negara sehingga menimbulkan rasa menghargai kepada ideologi yang sekiranya berbeda dengan negaranya sendiri.

\section{Pembentukan Kelompok Belajar}

Kelompok belajar dapat dikategorikan sebagai salah satu proses belajar nonformal yang dianggap paling efisien dan juga baik untuk menyaring pendapat-pendapat dari setiap orang guna menemukan hal yang paling baik dan juga masuk akal.menurut kelompok tersebut. Pembelajaran secara kelompok datau pembelajaran kooperatif adalah pembelajaran yang menekankan kerja kelompok dimana antar siswa dalam kelompok memiliki ketergantuangan satu sama lain untuk memperoleh hasil yang sama (MA, 2013).

Adanya penyuluhan terkait ilmu negara mengundang antusias dari siswa dan siswi kelas X IPS SMA 17 Agustus 1945 Surabaya maka dalam penyuluhan tersebut juga dibentuk adanya kelompok belajar yang dimana dalam kelompok belajar tersebut peserta di ajak untuk berdiskusi dengan teman-temanya untuk mempertimbangkan bentuk negara, dan juga ideologi negara yang seperti apa yang dapat mensejahterakan masyarakat yang ada dalam negara tersebut menurut mereka. Karena dengana adanya diskusi yang dilakukan tersebut paling tidak, diharapakan dengan diskusi itu mereka bisa membuka wawasan mereka terhadap apa yang berkembang (Ardhana, 2007).

Sehingga dengan adanya kelompok belajar tersebut membuat siswa dan siswi mempelajari sejarah dari bentuk-bentuk negara dan juga ideologi-ideologi yang di anut oleh negara-negara yang ada sehingga mereka tidak lagi menghakimi ideologi yang di anut negara lain yang memmang memiliki banyak hal berbeda dengan ideologi negara Indonesia. Dengan adanya kelompok belajar ini mereka juga banyak mempertimbangkan bentuk negara dan juga ideologi-ideologi yang menurut mereka dapat mensejahterakan rakyat yang ada di negara tersebut tetapi banuyak juga dari mereka yang telah menyadari bahwa bentuk dan juga ideologi yang dianut oleh negara Indonesia merupakan 
yang terbaik karena dapat menyatukan segala suku, ras, agama yang berbeda-beda di indoenesia dan juga dalam ideologi yang di anut oleh negra Indonesia ini tidak hanya memikirkan hal-hal terkait sosial dan politik melainkan juga dari sisi keagamaan turut dipikirkan sehingga kehidupan masyarakat didalamnya imbang antara kehidupan bersosial, dan politik.

\section{SIMPULAN DAN SARAN}

Dalam penyuluhan ini peserta di ajak untuk mengetahui tentang bentuk-bentuk negara yang ada diseluruh penjuru dunia yang dalam penyuluhan ini memiliki tujuan agar siswa dan siswi tersebut dapat membedakan bentuk-bentuk negara yang ada serta mengetahui ciri-ciri dari suatu negara yang memiliki bentuk tertentu yang memiliki perbedaan dengan negaranya Indonesia. Dalam penyuluhan tersebut, peserta juga diajak untuk berdiskusi dengan membentuk kelompok-kelompok belajar guna mempertimbadngakan bentuk negara dan juga ideologi negera seperti apa yang dapat mensejahterakan masyarakatnya. Dengan adnaya kelompok belajar ini peserta dapat mengetahui sejarah dari ideologiideologi negara yang dianut oleh berbagai negara sehingga tidak menimbulkan kesalah pahaman dan juga rasa saling menghargai ideologi yang di anut oleh negara-negara yang berbeda dengan Indonesia.

Selanjutnya, tim penulis menyarankan: (1) Perlulah adanya pembelajaran yang tidak hanya mengajarkan hal-hal terkait negara Indonesia saja, melainkan perlulah adanya pembelajaran yang juga mengajarkan tentang negara-negara lain yang memiliki perbedaan dengan Indoensia. Sehingga nantinya anak-anak akan mengetahui sejarah dari berbagai negara dan juga menghargai adanya perbedaan. Sehingga diharapkan anak-anak tidak dengan mudah memberikan penilaian yang buruk terhadap negara lain yang sekiranya memiliki perbedaan ideologi dengan Indonesia; (2) Perlulah adanya peningkatan literatur daring dan juga cetak yang memadai guna meningkatkan proses pembelajaran terkait ilmu Negara; (3) Untuk peneliti selanjutnya perlulah ada pengabdian yang dapat membahas tidak hanya dari aspek sosial dan politik tetapi perlu juga partisipasi dari setiap orang yang memiliki keilmuan dari hal ekonomi, teknologi, dan juga budaya contonya saja adalah penyuluhan tentang perekonomian yang ada dinegara-negara lain yang dapat dilakukan oleh mahasiswa dari fakultas ekonomi dan bisnis, adapun juga perlulah adanya partisipasi dari mahasiswa dan juga tenaga pengajar dari fakultas sosial dan budaya yang memberikan penyuluhan tentnag kebudayaan dari negara-negara yang ada di seluruh penjuru dunia dan juga penyuluhan dari fakultas teknik guna memberikan informasi-informasi terkait teknologi terbaru yang diciptakan oleh negara-negara yang memiliki inovasi teknologi-teknologi canggih. Semua itu perlu dilakukan agar nantinya jendela pengetahuan dari para siswa dan juga siswi makin terbuka dan diharapkan siswa dan juga siswi 
dapat menyerap hal-hal yang baik dan menciptakan hal baru yang orisinil karya anak bangsa

\section{UCAPAN TERIMA KASIH}

Penulis mengucapkan terima kasih yang sebesar-besarnya kepada SMA 17 Agustus 1945 Surabaya yang telah memberikan waktu dan kesempatan untuk dapat melaksanakan pengabdian berupa penyuluhan terkait Ilmu Negara. kami juga mengucapkan terimakasih kepada adik-adik Siswa dan Siswi Kelas X IPS SMA 17 Agustus 1945 Surabaya yang telah antusias mengikuti serangkaian proses penyuluhan, dan juga aktif dalam proses belajar kelompok dan tanya jawab sehingga suasana belajar pada penyuluhan kali ini terasa hidup dan dapat lebih mjudah dipahami oleh para siswa dan siswi.

\section{DAFTAR RUJUKAN}

Ardhana, K. (2007). Komunika majalah Ilimiah Komunikasi dalam Pembangunan.

Asmaun, S., Prasetyo, T., \& Angga. (2012). Desain Pembelajaran Berbasis Pendidikan Karakter. Research Repository.

Idi, A. (2011). Sosiologi Pendidikan Individu, Masyarakat, dan Pendidikan. Jakarta: Raja Grafindo Persada.

Kamal, M. (2016). Restrukturisasi Pendidikan Menuju Bangsa Berkarakter. Madaniyah, (kajian pendidikan, sosial dan keagamaan), 10.

MA, A. hamzah. (2013). PTK Tematik Integratif. Literasi Nusantara.

Nugroho, A. (2015). Pemahaman Kedudukan Dan Fungsi Bahasa Indonesia Sebagai Dasar Jiwa Nasionalisme. UNIB Jurnal, 5(11), 285-291.

Ritaudin, M. S. (2014). Wawasan Etika Politik, Membangun Sikap Kritis dan Rasional Politik Bangsa. Jurnal TAPIS, 10(2), 12-32.

Rizal Mustansyi. (n.d.). Notonagoro sebagai homo significans atas ideologi pancasila. Jurnal Filsafat, 39.

Supriyoko, K. (2010). Peran Pendidikan Dalam Membangun Moralitas Bangsa. Peran Pendidikan Dalam Membangun Moralitas Bangsa, 41-52. 